\title{
Biodiversity Beyond National Jurisdiction
}

\author{
(Intellectual) Property Heuristics
}

\author{
Siva Thambisetty
}

\begin{abstract}
в ВNJ negotiating positions on marine genetic resources are best understood in light of a number of hidden (intellectual) property heuristics at play - arising from the diverging relevance of tangibility and place when it comes to genetic resources and the asymmetry in IP norms in multilateral settings. This short paper sets out in outline, the normative implications of these heuristics and identifies a 'no harm' principle that ought to find a place in any new legally binding framework.
\end{abstract}

\section{Keywords}

biodiversity - areas beyond national jurisdiction - intellectual property - heuristics benefit-sharing - marine genetic resources - convention on biological diversity negotiations - digital sequence information - marine scientific research

Negotiations over biodiversity beyond national jurisdiction (BBNJ) negotiations up until the second intergovernmental conference (IGC2) and to a lesser extent in the third, ( $\left.\mathrm{IGC}_{3}\right)$ were awash with the canoe metaphor - that we are all in the same canoe perhaps a Pacific vaka, and needed to find direction and destination together. The canoe however, is a red herring, as it evokes the image of being together in warm seas with clear blue skies. A competing metaphor of an iceberg is more accurate because of the way the BBNJ negotiations subsume vastly significant, yet hidden, motivations. These hidden heuristics are important because they become short cuts for processing information and making judgments on negotiating positions. The subject matter of the BвNJ negotiations are complex, technical and difficult to fathom in their entirety for even seasoned negotiators. In this context it is critical that we bring much needed attention to the rules of thumb that are being used as a necessary 
aspect of understanding where progress might be made and to highlight textual limitations that threaten an ambitious Treaty.

In this paper I touch on two such heuristics in outline related to the (intellectual) property framework that is emerging in the text-based negotiations around marine genetic resources, excluding those related to capacity-building and technology transfer although some of these remain relevant. The first arises from the use of terms including 'genetic resources', 'access' and 'utilization'. The second heuristic is the long shadow cast by the skewed nature of intellectual property norms in multilateral settings and whether the consequences can and should be addressed or ameliorated in the B BNJ instrument or outside of it.

Use and Non-Use of Terms

In 1997 Laurenschlasger in an influential essay proclaimed 'Biodiversity is dead' to explain that the term 'biodiversity' was meaningless because of the ambiguity and breadth of the subject matter it refers to. ${ }^{1}$ For similar reasons it may be time to proclaim the death of 'genetic resources'. Evolving technologies have made this term a weighty anchor to the past hindering clarity and transparency of legal positions.

The Convention on Biological Diversity (СвD) is the ideational precursor to any ввлј framework. Here use of the term 'genetic resources' is tied to the land, to sovereignty and control by possession by State Parties. Genetic resources today exist in many different forms, physical and tangible but also dissociated, dematerialized and intangible in the form of digitized sequence data. ${ }^{2}$ What a particular negotiating party understands by the term 'genetic resources' depends on whether they see the putative international legally binding instrument (ILBI) as a relatively light touch instrument of environmental law dealing with biodiversity that is static, tied to place and tangibility; or an instrument of intellectual property law associated with functional information - manipulatable, free from geography and place and a function of the scientific and commercial benefits implied.

1 Laurenschlasger, 'Biodiversity is Dead', Wildlife Society Bulletin (1973-2006) 25(3) (Autumn, 1997), pp. 679-685.

2 See A Kostakis, 'Change and Subjectivity in International Environmental Law: The MicroPolitics of the Transformation of Biodiversity into Genetic Gold' Transnational Environmental Law, 3:1 (2014), pp. 127-147 and M Bagley, 'De-Materializing Genetic Resources: Synthetic Biology, Intellectual Property and the ABS By-pass' in C McManis and B Ong, Routledge Handbook on Biodiversity and the Law (Routledge 2018). 
The chasm between the old way of looking at biodiversity and the new, malleable way of characterizing genetic resources is hinted at in the definition of 'utilisation of genetic resources' in Art 2 of the Nagoya Protocol ${ }^{3}$ with its reference to 'the application of biotechnology'. There is currently a robust process underway initiated by the Conference of the Parties (COP) to examine the terminology and implementation of the $\mathrm{CBD}$ with reference to digital sequence information (DSI), itself a term used as a placeholder; ${ }^{4}$ other international bodies and frameworks are also realizing if not actively exploring, the significance of DSI under their own frameworks. ${ }^{5}$

There is wide divergence in how domestic measures that implement 'DSI'related measures under the CBD emerge and are applied in practice. The two extremes of the spectrum are marked by State Parties who see DSI as associated with physical and tangible resources such that contractual measures such as PIC and MAT would equally apply to them even though it is not clear how digitized sequence information that cannot contemporaneously be associated with a physical resource (for instance those stored or accessed ex situ in databases prior to entry into force of the Nagoya Protocol) will be governed. At the other end of the spectrum are those who see digitized sequence information as liberating the information from awkward and restrictive sovereign property rights.

The variance in domestic governance models that result is startling. ${ }^{6}$ It is in this context that the continued use of the term 'genetic resources' and replication of the confusion in 2020 in any в BNJ instrument, in so far as it signals dissociation from digitized forms of information would be unhelpful and regressive.

3 "The Nagoya Protocol on Access to Genetic Resources and the Fair and Equitable Sharing of Benefits Arising from their Utilization to the Convention on Biological Diversity" (CBD) is a 2010 supplementary agreement to the 1992 Convention on Biological Diversity.

4 Report of the Ad Hoc Technical Working Group on Digital Sequence Information on Genetic Resources, 20 February 2018, UN Doc. СBD/sBSTTA/22/INF/4 Available here < https://www.cbd. $\mathrm{int} / \mathrm{doc} / \mathrm{c} / 4 \mathrm{f} 53 / \mathrm{a} 660 / 20273$ cadac313787bo58a7b6/dsi-ahteg-2018-o1-o4-en.pdf $>$ and more recently Bagley, Karger, Mueller, Perron-Welch and Thambisetty, 'Fact-finding Study on How Domestic Measures Address Benefit-sharing Arising from Commercial and Non-commercial Use of Digital Sequence Information on Genetic Resources and Address the Use of Digital Sequence Information on Genetic Resources for Research and Development' (October 2019) Available here < https://www.cbd.int/dsi-gr/2019-2020/studies/\#tab=2> (Hereafter, 'Study 4 on Digital sequence Information on Genetic Resources').

5 The FAO this year invited submission of views on DSI, Available here < http://www.fao.org/ plant-treaty/overview/mypow/dsi/en/>. Also see Welch, Bagley, Kuiken, and Louafi, 'Potential Implications of New Synthetic Biology and Genomic Research Trajectories on the International Treaty for Plant Genetic Resources for Food and Agriculture (ITPGRFA or 'Treaty')' Emory Legal Studies Research Paper (2017).

6 Study 4 on Digital Sequence Information on Genetic Resources $n 4$ above. 


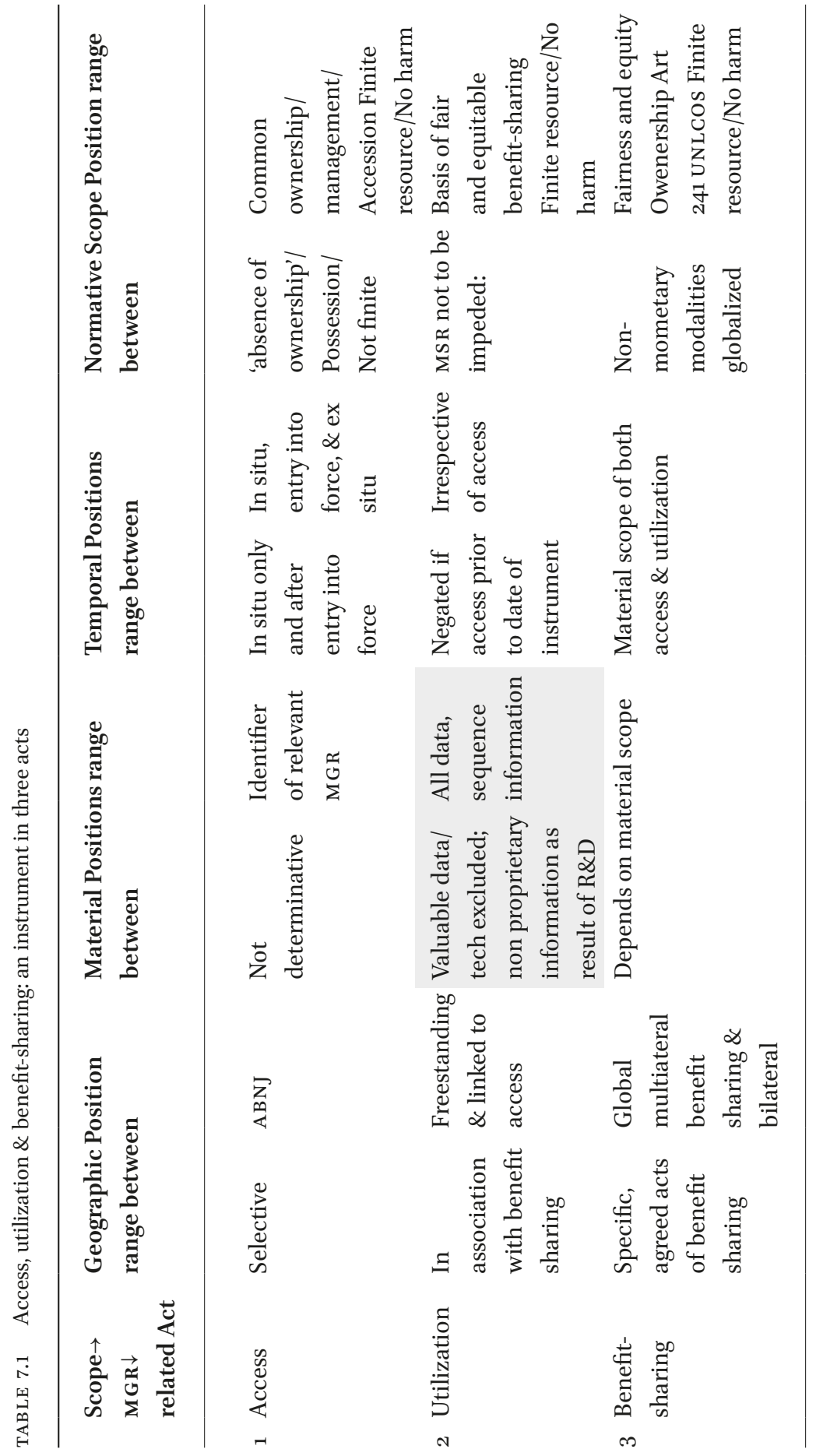




\section{Access, Utilization and Benefit-Sharing: An Instrument in Three Acts}

The zero-draft ${ }^{7}$ of the BBNJ instrument and ensuing negotiations are framed by three performative acts with potential legal implications - access, utilization and benefit-sharing. The geographical, temporal, material and normative scope of the instrument is distributed over these acts as laid out in Table 7.1. (see shaded boxes). In each case non-acceptance of DSI as an aspect of marine genetic resources of areas beyond national jurisdiction amplifies the complexity and incoherence of any frameworks put in place. In light of Table 7.1 and with respect to the state of negotiations in $\mathrm{IGC}_{3}$ it appears that the parties cannot agree on the scope of what it is that they are negotiating.

For example if DSI is not included within the scope of marine genetic resources being accessed, the conversion of a physical resource to digitized sequence information breaks the legal link between genetic resources accessed from areas beyond national jurisdiction $(\mathrm{ABNJ})$ and the sequence information. In effect any use of genetic resources accessed prior to the the entry into force of the ILBI will not be covered under it in its digitized form. Yet modern day utilization of genetic resources with some exceptions, ${ }^{8}$ can scarcely proceed without sequencing and digitization.

The above would be the case unless the 'utilization' of genetic resources undertaken after the entry into force of genetic resources accessed prior to the entry into force was an explicit trigger for the instrument to apply. ${ }^{9}$ When it comes to the utilization of genetic resources, State Parties to the Nagoya Protocol who choose not to associate DSI with physical genetic resources in effect negate the need to address benefit-sharing through the application of biotechnology under the Convention on Biological Diversity (СвD) ${ }^{10}$ (unless there are mutually agreed terms). This has cast a long shadow over any potential

$7 \quad$ Draft text of an agreement under the United Nations Convention on the Law of the Sea on the conservation and sustainable use of marine biological diversity of areas beyond national jurisdiction (A/CONF.232/2019/6) Available here < https://undocs.org/en/a/ conf.232/2019/6>.

8 For example, taxonomy or conservation measures.

9 It is critical to note here that utilization of genetic resources accessed prior to entry into force will not necessarily amount to retrospective application of the instrument. The rule against retroactivity in Art 28 of the Vienna Convention only applies in the absence of a different intention that can be established by the parties.

10 Although this can still happen through compliance measures designed to ensure that provider country laws that do reference DSI are followed. See discussion of EUR 511/2O14 in 'Study 4 on Digital sequence Information on Genetic Resources' n 4 above. 
benefit-sharing in the BBNJ negotiations with several negotiating parties such as the EU and Japan taking the view that 'utilization' of genetic resources need not find a place in the text of the ILBI. ${ }^{11}$ If 'utilization' remains undefined, then benefit-sharing arising from the utilization of genetic resources cannot possibly be pinned down.

Problems defining benefit-sharing go beyond a mere question of use of terms. There is the issue of monetary and non-monetary benefit-sharing, and determining commercial and non-commercial contexts. ${ }^{12}$ The more acute problem here however is the lack of agreement on the meaning and status of benefitsharing, which in the language of both UNGA Resolutions that set the stage for the negotiations is one of four key questions the instrument must address. ${ }^{13}$

Benefit-sharing or in some cases 'fair and equitable benefit-sharing', as the third performative act related to marine genetic resources from ABNJ appears to be used both as short-hand for a principle of international law and as a mere modality. There are some indications that benefit-sharing is now of sufficient heft and weight that it should be regarded as a principle of international law. Equitable benefit-sharing so far has been recognised as 'a Treaty objective, obligation and mechanism under biodiversity laws, a component of the human right to science, and relevant to international biodiversity law as well: ${ }^{14}$ Yet we do not have an explicit or principled approach to what it means to 'share' and when such sharing is 'fair and equitable'.

Alternatively to view benefit-sharing as a functional modality is to restrict its scope to specific, enumerated contexts that inherently limit any ambitions for multiple avenues of justice that may flow from a more opentextured principle of international law. We see this play out in the context of the $\mathrm{CBD}$, where benefit-sharing can be difficult to enforce. The bilateral architecture of the Convention means benefit-sharing is essentially a modality that is subject to international contract law, with all the difficulties of performance and enforcement that entails. ${ }^{15}$ An approach that takes into

\footnotetext{
11 Based on $\mathrm{IGC}_{3}$ negotiations on MGRs.

12 C von Kries and G Winter, 'Defining commercial and non-commercial research and development under the Nagoya Protocol and in other contexts', in E Chege Kamau, G Winter, PT. Stoll, (eds.), Research and Development on Genetic Resources: Public Domain Approaches in Implementing the Nagoya Protocol (Routledge 2015).

13 Resolution 69/292 (19 June 2015) and Resolution 72/249 (24 December 2017).

14 E Morgera, 'Fair and Equitable Benefit-Sharing: History, Normative Content and Status in International Law' in Benefit-sharing' in E Orlando and L Krämer, (eds.), Encyclopedia of Environmental Law: Principles of Environmental Law (EE 2017).

15 T Young and M Tvedt, Drafting Successful Access and Benefit-Sharing Contracts (Brill Nijhoff 2018).
} 
account human rights, the achievement of UNSDG s, and the status of the resources of ABNJ could see Equitable Benefit-Sharing (EBS) as a principle of public international law designed to further equity and open to evolving interpretation.

The legal weight of this international legal principle in the making is set to be a matter of discussion for some time to come. The BBNJ instrument will inevitably act as a bridge between those who see benefit-sharing as merely instrumental to a subjective vision of the framework and others who see it as a necessary requisite for justice and progress for 'all peoples of the world. ${ }^{16}$ In the interests of coherence, negotiators must anticipate and reduce the potential for dissonant approaches.

\section{3}

\section{Intellectual Property Norms}

IP norms are often presented in the form of simplistic heuristics, heightened by asymmetry in the way they originate and are applied in multilateral settings and due to their perceived consequences. This asymmetry has played out for instance in the loss of regulatory sovereignty related to domestic innovation policies $^{17}$ and an increasing inability to mediate public policy related to the intersection of IP with environmental, social and economic policies derived from other multilateral settings. ${ }^{18}$ It is also hard to ignore critiques of the failings of intellectual property frameworks in domestic contexts in leading jurisdictions like the United States and in EU law. ${ }^{19}$ The asymmetry has led some academics, including Professors Ruth Okediji and Jerome Reichman, to call for a moratorium on the further harmonization of intellectual property at

16 United Nations Convention on the Law of the Sea, Preamble, emphasis added.

17 See Declaration on Patent Protection: Regulatory Sovereignty under TRIPS, available here <https://www.mpg.de/8132986/Patent-Declaration.pdf>; G Shaffer, 'How the WTO Shapes Regulatory Governance' University of California, Legal Studies Research Paper Series No. 2014-53.

18 Braga, Fink and Sepulveda, 'Intellectual Property and Economic Development' World Bank Discussion Paper 412 (2000).

19 K Aoki, 'Distributive and Syncretic Motives in Intellectual Property Law (with Special Reference to Coercion, Agency, and Development)'4o U.C. Davis L. Rev. 717- 801 (2007); A Jaffe and J Lerner, Innovation and Its Discontents: How our Broken Patent System is Endangering Innovation and Progress, and What to Do About it (Princeton University Press 2007); J Bessen and M Muerer, Patent Failure: How Judges, Bureaucrats, and Lawyers Put Innovators at Risk (Princeton University Press 2009); D Guellec and B V Pottelsberghe de la Potterie, The Economics of the European Patent System: IP Policy for Innovation and Competition (OU P 2007). 
regional and multilateral levels, a call fueled at least partially by the 'tentative and divergent ideas about how best to treat a daunting array of new technologies.' ${ }^{20}$ For the ввNJ process the question is whether there is a constructive way to acknowledge these developments in the negotiations, and whether not doing so is in effect an explicit acceptance of the skewed nature of some of these norms.

In the text-based negotiations, there seem to be four different scenarios emerging:

\section{The 'no text' Option - Intellectual Property Law Is Not Addressed in} the ILBI with Respect to Marine Genetic Resources

As Table 7.1 tries to convey, not addressing arrangements that govern valuable data and technology (see shaded boxes) threatens coherence of the eventual instrument. Resolving the 'value' that arises from the utilisation of marine genetic resources is best done through a deeper engagement with means of control over information - predominantly through intellectual property, but also through careful management of the public domain and open access measures. To negotiate only the latter without addressing the former through IP arrangements cuts away a sizeable chunk of the potential scope of the instrument.

The place and precarity of intellectual property rights over genetic resources have shadowed the growth of biotechnology right from the start. The СвD does not address intellectual property rights over genetic resources, but this may be seen as a function of the fact that it predates the TRIPS agreement and the efforts to harmonise IP standards globally. Unequivocal sovereign rights granted to State Parties over genetic resources in their territories preserved a semblance of control over the use and circulation of genetic resources, in a world not yet enthralled with global intellectual property rules. Contemporaneoulsy, the human genome project, accompanied by studies on ELSI - ethical, legal, social issues - was shadowed right from the start by the implications of commodifying genes, and the facilitation of it via patents and exclusionary licensing terms. ${ }^{21}$ Subsequent developments in synthetic biology have served

20 J H Reichman \& R C Dreyfuss, 'Harmonization Without Consensus: Critical Reflections on Drafting a Substantive Patent Law Treaty', 57 Duke L.J. 85, 86 (2007); Ruth Okediji, 'Does Intellectual Property Need Human Rights' 51 NYUJ Int'l \& Pol 1 (2018).

21 See D Dickenson, 'Consent, Commodification, and Benefit-Sharing in Genetic Research', Dev World Bioethics 2004 4(2):109-24; and Goulding, Marden, Manion, Levy, 'Alternative Intellectual Property for Genomics and the Activity of Technology Transfer Offices: Emerging Directions in Research', 16 BUJ Sci \& Tech L 194 (2010). 
to heighten concerns over the distributive effects of patents, and the widening technology capability gap. ${ }^{22}$

The 'no text' viewpoint is often accompanied by a non-specific suggestion that other institutions and entities are better suited to address the question of intellectual property rights over marine genetic resources of ABNJ, despite the fact that the two main contenders, the World Intellectual Property Office (WIPO) and the World Trade Organisation (WTO), have shown no appetite to take on the issue of marine genetic resources in ABNJ. Recent negotiations at the WIPO on declarations of origin include text that specifically excludes MGR S of ABNJ. ${ }^{23}$ The WTO also has shown little disposition towards overextending its legitimacy in unconventional ways, ${ }^{24}$ and it is extremely unlikely that the Agreement on Trade-Related Aspects of Intellectual Property Rights (TRIPS) Council will see the ABNJ origins of these marine genetic resources as being reason enough to amend provisions of the TRIPS Agreement.

Given that: 1) in most jurisdictions it is possible to patent microrganisms, genomic $\mathrm{DNA}^{25}$ and gene sequence fragments, and that such patents amount to exclusive monopolies over the use and commercial exploitation of genes and associated digital sequence information; 2) there is continuing pressure to harmonise intellectual property standards worldwide; 3) ABNJ has unprecedented legal status, the 'no text' option under the rubric of Article 12 of the zero draft is in effect an endorsement of the status quo. It would be fair to say that those endorsing such status quo are the State Parties where individuals and corporations benefit most from existing arrangements around the monopolisation of genetic resources. The long-standing nature of the problems over

22 Welch, Bagley, Kuiken and Louaf, 'Potential implications of new synthetic biology and genomic research trajectories on the International Treaty for Plant Genetic Resources for Food and Agriculture (ITPGRFA or 'Treaty')' $\mathrm{n} 5$ above.

$23 \mathrm{WIPO} / \mathrm{GRTKF} / \mathrm{IC} / 40 / 6$ (April 9, 2019) see text under draft Article 5.

24 A Lang, World Trade Law after Neoliberalism: Reimagining the Global Economic Order (Oxford: Oxford University Press, 2011). Also see M Fakhri, 'Reconstruing WTO Legitimacy Debates' (2011) 2 Notre Dame J of Int'l \& Comp L, 64.

25 R Cooke-Degan and C Heaney, 'Patents in Genomics and Human Genetics' Annu Rev Genomics Hum Genet 2010 Sep 22; 11: 383-425; The US Supreme Court in 2013 recognised that genomic DNA ought not to be monopolised through patents in Association for Molecular Pathology v, Myriad, 569 U.S. 576 (2013); however the position in most jurisdictions is harmonised to the contrary. See 'Genetics, Genomics and the Patenting of DNA: Review of Potential Implications for Health in Developing Countries' (wHO 2005). 
such monopolisation however, makes acquiescing in this way problematic and should give all negotiating parties pause for thought.

\section{(b) The 'tinkering' Option - Ameliorating Existing Frameworks}

If there is some misgiving about how IP will apply, particularly over DSI and patent office actions, then it makes sense to find measures that ameliorate some of the excesses of the system. A number of negotiating parties have spoken of measures such as declaration of origin or conditions of access that implement a form of 'track and trace' so that marine genetic resources accessed from $A B N J$ can be identified as such through the value chain. When speaking of track and trace it is important to acknowledge that it is both scientific and legal in character and that the scientific possibility need not be determinative of the latter. ${ }^{26}$ In medical and scientific research, honour systems and codes of conduct policed by peers and self-regulatory measures are not uncommon. A similar system could supplement scientific tracing and give content to meaningful 'track and trace' but only if the ILBI sets out at least a nominal basis for it. ${ }^{27}$

Legal track and trace would need monitoring mechanisms. Under the Nagoya Protocol, intellectual property offices are the most commonly used checkpoints. ${ }^{28}$ A different approach can also be taken by incorporating the international patent classification system. This is a system for examiners in patent offices or others to categorise, classify and code patent applications according to the technical features of their content, enabling technical data to be retrieved easily. ${ }^{29}$ Modifications to the international classification system are made all the time, as technology develops or unprecedented innovations come up. With some basis in the ILBI to do so, it should be possible to explore a new sub-group classification referring to marine genetic resources from ABNJ. This

26 See discussion in S Thambisetty, 'Marine Genetic Resources Beyond National Jurisdiction: Elements of a New International Legally Binding Instrument', LSE Law-Policy Briefing Paper No. 32. Available here < https://papers.ssrn.com/sol3/papers.cfm?abstract_ id $=3^{219995}>$.

27 For an in-depth analysis see B Kiliç, 'Patent Disclosure Requirements in Free Trade Agreements', paper commissioned by the Centre for wTO Studies for the International Conference on TRIPS-СвD linkages, Geneva (Switzerland), 7-8 June 2018, available at: http://wtocentre.iift.ac.in/workingpaper/WorkingPaper49.pdf.

28 Study 4 on Digital sequence Information on Genetic Resources $n+4$ above.

29 Established by the Strasbourg Agreement https://www.wipo.int/classifications/ipc/en/ preface.html. 
would have the advantage of being embedded in the patent system and be non-discriminatory of patent applicants. ${ }^{30}$

The ideal substantive legal basis in the ILBI would be for declaration of origin to be adopted as a non-monetary benefit-sharing measure on the bases that recording provenance is good science and enhanced patent disclosure measures can lead to positive information spill overs for everyone and facilitate benefit-sharing. Crucially, declaration of origin appears to reflect the direction of travel under the CBD and Nagoya Protocol. ${ }^{31}$ It should also be noted that since none of the countries that have opted for some form of declaration of origin for patent applications have been taken to task at the wTO yet, such measures are conceivably compatible under the TRIPS Agreement. ${ }^{32}$ In light of the ease with which some form of declaration of origin may be legally implemented in case of MGRs post entry into force of a putative instrument, the onus surely shifts to asking negotiating parties to justify the continued demand for non-disclosure of origin.

\section{(c) The 'no-IPR' Option: Precluding Intellectual Property}

The third option that is emerging is where some negotiating parties want to make the ownership structure over marine genetic resources of $\mathrm{ABNJ}$ fair and equitable by precluding intellectual property rights (IPR). The normative basis for this comes from UNCLOS Art 241, particularly as there now seems to be growing convergence on the view that marine scientific research (MSR) includes research on genetic resources. ${ }^{33}$ It is supplemented by the common heritage of mankind principle put forward robustly by the G77 + China group as dispositive of the status of marine genetic resources beyond ABNJ.

This brings us to one of the most simplistic heuristics in the BBNJ negotiations - that the common heritage of mankind ( $\mathrm{CHM}$ ) and freedoms of the high

30 See discussion in C Chiorolla, 'Intellectual Property from a Global Environmental Law Perspective: Lessons from Patent Disclosure Requirements for Genetic Resources and Traditional Knowledge', Transnational Environmental Law, 8:3 (2019), pp. 503-521.

31 See references to check points in 'Study 4 on Digital sequence Information on Genetic Resources' and C Chiorolla, $\mathrm{n} 30$ above on the 'quasi-extraterritorial application of ABS standards' at 512 .

32 C Chiarolla, $\mathrm{n} 30$ above [fn 74$]$.

33 Based on negotiations at IGC3. Article 241 UNCLOS states that MSR 'shall not constitute the legal basis for any claim to any part of the marine environment or its resources'. See M Ysern (2003), 'Legal issues raised by profitable biotechnology development through MSR' American Society of International Law (www.asil.org/insights) p. 2 arguing that claims regarding intellectual property rights in these developments would in fact constitute a 'claim' under Article 241. 
seas (FoHS) are mutually exclusive ${ }^{34}$ - that you cannot opt for one without also denigrating the significance of the other. This is possibly at the heart of the recalcitrance to address normative principles in text-based negotiations over BвNJ, and the disappearance of the снм and FoHS between the first President's "Aid to the Negotiations" document and the zero-draft text. Following conventional negotiating theory, it makes sense to agree on non-controversial aspects before tackling the main sources of divergence, ${ }^{35}$ but the inability to resolve the status of these two principles is having a detrimental impact on normative coherence as it applies to intellectual property issues.

With respect to the status of marine genetic resources, $\mathrm{CHM}$ and FoHS do not occupy the same space. The former refers to the ethical and legal status of the subject area and resource (absence of private property rights being one aspect), and the latter is a freedom in relation to an area (beyond national jurisdiction) and should not be confused with a non-existent freedom to lay claim through property rights to the fruits of exercising that freedom (whether through MSR or otherwise), including through intellectual property rights. It is this necessary distinction that is captured by the restraint in Article 241 of UNCLOS.

The right to conduct MSR and access and utilise marine genetic resources from $A B N J$ as a seamless continuum only works if you acknowledge a facilitative normative basis that allows for possession of those resources. If we accept that the FoHS applies to MSR, then in so far as possession of MGRs resulting from MSR are concerned two potential possibilities follow - that biodiversity

34 See discussion for instance in P Taylor, 'Common Heritage of Mankind Principle' in K Bosselmann, D Fogel, and J. B. Ruhl, (eds.), The Encyclopedia of Sustainability, Vol. 3: The Law and Politics of Sustainability 64-69. (Berkshire Publishing); and D Tladi 'State Practice and the Making and Remaking of International Law: The Case of the Legal Rules Relating to Marine Biodiversity in Areas Beyond National Jurisdiction', (2014) 1 J of State Practice and International L, 97; and Z Chun, 'Challenges Facing the UN High Seas Treaty', The Maritime Executive (Editorial) 2018-o9-07 Available here < https://www.maritimeexecutive.com/editorials/challenges-facing-the-un-high-seas-treaty (referring to traditional ideas around freedom of the high seas, and the halting recognition of biodiversity of the high seas).

35 For general discussion on ordering negotiating priorities see K Monheim, "The management of multilateral negotiations: lessons from UN climate negotiations' February 2015 Policy Paper, Grantham Research Institute on Climate Change and the Environment, Available here $<$ http://eprints.lse.ac.uk/64534/1/Managment-of-multilateral-negotiations_ Monheim_final.pdf> and N Kteily, T Saguy, J Sidanius, and D M Taylor, Negotiating Power: Agenda Ordering and the Willingness to Negotiate in Asymmetric Intergroup Conflicts', J of Personality and Social Psychology 2013 105(6), 978-95. 
beyond national jurisdiction is regarded as being under common ownership, or that no ownership rights exist whatsoever.

Purely on the basis of precedent, СнM is de facto an unconvincing practical basis for precluding intellectual property rights. As a principle it is widely seen as enabling distributive justice for developing countries and facilitative of benefit-sharing. In international law there is no definition of CHM as such, only an agreement on constituent elements. The UN Framework Convention on Climate Change and the Convention on Biological Diversity both water down the principle to 'common concern of mankind'; and the UNEsco Declaration on the Human Genome and Human Rights refers to the human genome as 'heritage of humanity in a symbolic sense'. These sorts of depictions do not prevent the private ownership of genomic data (human, plant or animal) through patents and incorporation in privately owned databases. As a principle of international law, it is an ambiguous placeholder that lends itself to dilution and multiple interpretations.

The FoHS and uninhibited access works best within the assumption that вв NJ is 'owner-less' but this appears to go against the language of UNGA Resolutions $72 / 249$ and 69/292 which set out the need for a 'comprehensive global regime' to better address conservation and sustainable use of marine biological diversity of areas beyond national jurisdiction. The language is redolent of managed 'common ownership', rather than a laissez faire, 'no-ownership' scenario. In order for the FoHS to be compatible with the wording of the relevant UNGA resolutions in a way that ties that principle to access and utilisation of MGRs, the status of these resources in law, and intellectual property rights, we need persuasive arguments that I believe have not been put forth yet.

\section{Moderation and Regulatory Sovereignty: Intellectual Property Limitations}

Limiting intellectual property rights rather than precluding these rights allows for the moderation of the scope of these rights. A BBNJ instrument could have a choice of being either prescriptive or leaving the precise contours of such limitations to domesticate regulatory sovereignty. This is for instance reflected in the language put forth by the PSIDs group in its position on Article 12 of the zero-draft. ${ }^{36}$

36 Article 2 bis The access, utilization and commercial exploitation of marine genetic resources under this Agreement and protected by intellectual property rights shall be subject to limitations that further the objectives of this Agreement and this Part, including equitable benefit sharing and capacity building and technology transfer. (Conference Room Papers Aug 30 2019). 
The architecture of limitations is internal to intellectual property law internationally and is therefore not likely to damage the coherence of the transnational application of the ILBI. These limitations would apply to the post grant exploitation of intellectual property rights such as patents, could be automatic (such as 'fair use' terms in copyright law), or be an effective means to control price, access (through licensing terms), or availability (through measures that demand local working of patented inventions for example.) They may apply in a time-limited way - for instance granting least developed countries and small island developing states, a longer period to apply IP rules taking into account their special circumstances. Whether such limitations would be compatible with TRIPS is a critical question, but on balance such measures could be seen as furthering the objectives of Articles 7 and 8 of TRIPS, consistent with socioeconomic differences and technological development amongst countries. ${ }^{37}$ Such limitations would take into account the disputed normative basis of вв $\mathrm{NJ}$ without needing to resolve it and give weight to Art 241 UNCLOS.

A helpful precedent can be seen in the Marrakesh Treaty ${ }^{38}$ negotiated at WIPO, which allows countries to institute a limitation or exception in copyright laws to facilitate books to be converted into a format that is accessible to people who are visually impaired. This removes barriers faced by persons with visual impairments from accessing published works, ending a "book famine" for people with such disabilities. Less than $5 \%$ of all books ever published in the world are available in formats that can be accessed by the visually impaired. ${ }^{39}$

That process analogous to the one we are contemplating here, was driven by the need to achieve 'equal opportunities including the freedom to seek, receive and impart information and ideas of all kinds on an equal basis with others, including through all forms of communication of their choice, their enjoyment of the right to education and the opportunity to conduct research and to share scientific progress and its benefits. ${ }^{40}$ There are lessons in the way the world came together then for the ввNJ instrument now, as some negotiating parties try to pre-empt an impending 'marine technology famine' by improving access to valuable technologies and products that result from MSR conducted in ABNJ.

37 Article $7,8.1$ and 8.2 of the TRIPS Agreement.

38 Treaty to Facilitate Access to Published Works for Persons Who Are Blind, Visually Impaired, or Otherwise Print Disabled (2013).

39 L Ayoubi, "The Marrakesh Treaty: Fixing International Copyright Law for the Benefit of the Visually Impaired Persons', (2015) 13 NZJPIL.

40 Marrakesh Treaty to Facilitate Access to Published Works for Persons Who Are Blind, Visually Impaired or Otherwise Print Disabled, Preamble. Available here <http://www. wipo.int/wipolex/en/treaties/text.jsp?file_id=301019> 
These four emerging positions are set out within the rubric of Articles 10, 11, 12 and 13 of the zero-draft treaty. Through this suite of Articles, the ILBI will form a link between the normative basis of control over the physical resources and the intangible information that is an integral part of marine genetic resources. Whichever side of the spectrum - 'common ownership' or 'no ownership' - the dust ultimately settles, I submit that it must be guided by a 'no harm' principle which must apply across the board.

One of the most detrimental impacts and a very well-hidden heuristic of focussing solely on the physicality of marine genetic resources is that they are seen as replenishable, inexhaustible and 'not finite' as a resource. This is the basis of assertions such as Japan's in open session in IGC2 - that a bucket of water in order to conduct genetic sampling is not going to 'harm' the marine environment. However, if we view marine genetic resources as a combination of physical and intangible, then monopoly rights over dematerialised resources make them finite, exhaustible and liable to monopolistic use. This is where the potential 'harm' is located - in the information deprivation caused by intellectual property rights that assign exclusive rights to informational, functional or contextual content of genetic resources. To ensure that the ILBI does not facilitate such impoverishment, it is important for the framework to ensure a 'no harm' principle - that when MSR is conducted, 'enough and as good' is left over for others that come after. ${ }^{41}$ This is patently incompatible with unrestricted intellectual property rights over marine genetic resources of the ABNJ.

To third party observers, it can seem as if the BBNJ negotiations are a performance of justice, of process and of reasonableness rather than a meeting of minds over outcomes. Whether a balanced textual outcome can result from the multilateral negotiating process remains to be seen. What I have tried to show in this short paper is the need to bear in mind existing frames of understanding out of which the new governance regime will inevitably be fashioned. Even if we cannot all agree on ideal outcomes, we should be able to agree on the need for coherence and relevance in the text, as a consequence of which just outcomes may perhaps, become possible.

41 This clause in Ch 5 of Locke's Second Treatise is widely seen as a necessary restriction on private acquisition of the natural world $(\mathrm{ABNJ})$ by application of one's labour (MSR). For discussion of this orthodoxy on the principles of first appropriation and challenges to it see J Tomasi, 'The Key to Locke's Proviso', British Journal for the History of Philosophy, 6:3, 447-454 DOI: 10.108 o/og6o8789808571006. 
Siva Thambisetty - 9789004422438

Downloaded from Brill.come4/25/2023 11:25:42PM via free access 